\title{
PENERAPAN MODEL PEMBELAJARAN KOOPERATIF TIPE INVESTIGASI KELOMPOK DALAM PEMBELAJARAN BIOLOGI UMUM
}

\section{APPLICATION OF COOPERATIVE LEARNING MODEL FOR GROUP INVESTIGATION TYPE IN GENERAL BIOLOGY LEARNING}

\author{
Mohammad Liwa Ilhamdi dan I Gde Mertha \\ Dosen Program Studi Pendidikan Biologi FKIP, Universitas Mataram, Indonesia \\ Email: liwa_ilhamdi@yahoo.co.id
}

Diterima: 8 Oktober 2019. Disetujui: 8 Oktober 2019. Dipublikasikan: 9 Januari 2020

\begin{abstract}
Abstrak: Tujuan penelitian untuk menerapkan model Pembelajaran kooperatif tipe investigasi kelompok dalam meningkatkan hasil belajar Biologi Umum mahasiswa program Studi Pendidikan Matematika FKIP Unram 20192020. Jenis penelitian ini adalah penelitian tindakan kelas dengan 2 siklus. Tiap siklus terdiri dari tahap perencanaan, pelaksanaan, evaluasi dan refleksi. Hasil penelitian menunjukkan bahwa hasil belajar dari 35 orang mahasiswa pada siklus 1 nilai rata-ratanya 63,7. jumlah tuntas 27 mahasiswa (77\%), tidak tuntas 8 orang (23\%). Siklus ke 2 jumlah mahasiswa yang tuntas 30 orang $(85,7 \%)$ dan yang tidak tuntas 5 orang $(14,3 \%)$ dengan nilai rata-rata 72. Kesimpulan penelitian penerapan model pembelajaran tipe investigasi kelompok dapat meningkatkan hasil belajar biologi umum mahasiswa program studi pendidikan matematika FKIP Unram 2019-2020.
\end{abstract}

Kata kunci : Investigasi kelompok, hasil belajar, biologi umum

\begin{abstract}
The aim this research is to apply the cooperative learning model of group investigation type in improving the learning achievement General Biology students of Mathematics Education Study Program Faculty of Teacher Training and Education Mataram University lesson year 2019-2020. Type of research is classroom action research with 2 cycles. Each cycle consists of the planning, implementation, evaluation and reflection. The results showed that the learning achievement of 35 students in first cycle averaged 63.7. There are 27 students (77\%) completed, 8 students $(23 \%)$ incomplete. In the second cycle the number of students who completed 30 student $(85.7 \%)$ and those who did not complete 5 student (14.3\%) with an average value of 72 . Conclusions of the research application of the learning model of group investigation can improve the general biology learning achievement of Mathematics Education Study Program Faculty of Teacher Training and Education Mataram University in lesson year 20192020.
\end{abstract}

Keywords: Group investigation, learning achievement, general biology

\section{PENDAHULUAN}

Pembelajaran dengan melibatkan peran aktif mahasiwa penting dilakukan karena pembelajaran akan lebih bermakna bila mahasiswa diberikan kesempatan untuk berpartisipasi dalam berbagai aktivitas kegiatan pembelajaran. Sementara itu, dosen berperan sebagai fasilitator dan mediator sehingga mahasiswa mampu berperan dan berpartisipasi aktif dalam mengaktualisasikan kemampuannya di dalam dan di luar kelas [1-2]. Dalam hal ini, dosen harus memberikan kesempatan kepada mahasiswa untuk bertanya, mengemukakan ide dan saran serta memecahkan masalahnya sendiri, sehingga mahasiswa diharapkan memperoleh pengalaman belajar dan memiliki keterampilan berpikir yang kritis, kreatif, motivasi belajar yang tinggi serta tumbuhnya rasa tanggungjawab pada diri mahasiswa [3-4].
Peraturan Pemerintah Nomor 19 tahun 2005

Pasal 19 mengamanatkan agar pembelajaran dilakukan secara interaktif, inspiratif, menyenangkan, menantang, memotivasi peserta didik untuk berpartisipasi aktif, serta memberikan ruang yang cukup bagi prakarsa, kreativitas, dan kemandirian sesuai dengan bakat, minat dan perkembangan fisik, serta psikologis peserta didik dan memberi keteladanan [5]. Amanat pendidikan ini tentu tidak hanya mengacu pada keberhasilan belajar mahasiswa yang berupa angka-angka, akan tetapi merujuk pada keberhasilan pembelajaran itu sendiri. Menurut Rogers dalam Sagala (2008) bahwa praktek pendidikan menitik beratkan pada segi pengajaran, bukan pada mahasiswa yang belajar. Praktek tersebut ditandai oleh peran pendidik yang dominan dan peserta didik menghafalkan pelajaran. Sejalan dengan itu, paradigma pembelajaran yang berpusat pada dosen (teacher centered) seharusnya diubah menjadi 
paradigma pembelajaran yang berpusat pada mahasiswa (students centered) [6].

Pembelajaran kooperatif sangat penting untuk mendukung kegiatan pembelajaran berbasisis inkuiri, membimbing dan memfasilitasi proses pemeblajaran, serta mendesain dan mengelola lingkungan belajar. Pembelajaran kooperatif dapat memberikan pengalaman belajar dengan membangun saling ketergantungan positif antar sesama anggota kelompok, mengembangkan tanggungjawab individual, dan keterampilan bekerjasama secara seimbang. Dengan melaksanakan pembelajaran kooperatif, mahasiswa dapat meraih keberhasilan dalam belajar, disamping itu juga melatih mahasiswa untuk memiliki keterampilan, baik keterampilan berpikir (thinking skill) maupun keterampilan sosial (social skill) [7-12].

Upaya dalam mengkondisikan kegiatan pembelajaran sehingga kegiatan pembelajaran menjadi lebih bermakna adalah dengan pembelajaran investigasi kelompok karena peserta didik merasa lebih senang dalam belajar, kemampuan berpikir mahasiswa akan semakin dikembangkan, serta interaksi yang terjadi di dalam pembelajaran itu sendiri menjadi interaksi yang dinamis antara mahasiswa dengan dosen maupun mahasiswa dengan mahasiswa lainnya. Investigasi kelompok merupakan tipe pembelajaran kooperatif yang kompleks karena memadukan antara prinsip belajar kooperatif dengan pembelajaran yang berbasis konstruktivisme dan prinsip pembelajaran demokrasi. Tipe ini dapat melatih mahasiswa untuk menumbuhkan kemampuan berpikir mandiri. Dalam pelaksanaan tipe ini, interaksi sosial dijadikan faktor yang sangat penting bagi perkembangan skema mental yang baru. Disinilah pembelajaran kooperatif memainkan perannya di dalam memberi kebebasan kepada pembelajar untuk berpikir secara analitis, kritis, kreatif, reflektif, dan produktif. Dengan demikian motivasi mahasiswa akan mengalami peningkatan karena mahasiswa yang biasanya dijadikan obyek pembelajaran oleh dosen, pada penerapan model pembelajaran kooperatif tipe investigasi kelompok ini mahasiswa juga dilibatkan langsung dalam penentuan pembelajaran. Jika motivasi belajar meningkatkan pada akhirnya akan meningkatkan hasil belajar [1315].

Selain itu juga model pembelajaran kooperatif tipe investigasi kelompok mahasiswa dapat mengorganisasikan kemampuannya di dalam memecahkan suatu masalah (problem solve). Karena dalam penerapan model pembelajaran kooperatif tersebut diharapkan menghasilkan peningkatan kemampuan akademik, meningkatkan kemampuan berfikir kritis, membentuk hubungan persahabatan. Selain itu juga, diharapkan dapat menumbuhkan motivasi mahasiswa dalam belajar, saling berkerja sama dalam kelompok, serta interaksi belajar yang terjadi di dalam kelas menjadi interaksi yang bersifat dinamis. Penelitian ini fokus pada upaya memperbaiki kualitas pembelajaran di kelas terutama pada siswa calon guru di program Studi Pendidikan Matematika FKIP Unram 2019-2020 dengan menerapkan model pembelajaran kooperatif tipe investigasi keleompok.

\section{METODE PENELITIAN}

Jenis penelitian ini adalah penelitian tindakan kelas yang dilakukan oleh peneliti di dalam kelas dengan tujuan untuk memperbaiki kualitas pembelajaran di kelas. Penelitian ini dilaksanakan di prodi Matematika kelas E FKIP Unram dengan jumlah mahasiswa 35 orang terdiri dari laki-laki 2 orang dan perempuan 33 orang. Desain penelitian tindakan kelas ini adalah desain yang dikembangkan oleh Kemmis dan Mc. Taggart. Model ini terdiri dari empat komponen yaitu rencana, tindakan, observasi dan refleksi. Penelitian ini dilaksanakan dalam 2siklus.

Tehnik pengumpulan data dengan tes dan observasi. Indikator merupakan patokan untuk menentukan keberhasilan suatu kegiatan atau program. Suatu program dikatakan berhasil apabila mampu mencapai indikator yang telah ditentukan atau gagal apabila tidak mampu mencapai indikator yang telah ditentukan.

Indikator dalam penelitian ini digunakan untuk memberikan makna terhadap keberhasilan setelah pelaksanaan tindakan. Indikator yaitu suatu hasil setelah tindakan dibandingkan dengan standar minimal yang ditentukan yaitu: 1). Untuk melihat keberhasilan aktivitas dosen diukur dengan melihat skor yang diperoleh berkategori baik, aktivitas mahasiswa berkategori aktif. 20. Hasil belajar mahasiswa dikatakan tuntas secara klasikal jika $85 \%$ mahasiswa mencapai nilai 75 .

Pembalajaran pada Siklus I meliputi:

1) Perencanaan (Planning)

Hal-hal yang dilakukan pada tahap perencanaan ini adalah: a). Membuat scenario pembelajaran dengan menerapkan model pembelajaran kooperatif tipe investigasi kelompok. b) Menyiapkan media, alat dan bahan yang dibutuhkan dalam pembelajaran. c) Menyusun lembar obsevasi untuk menilai situasi belajar mengajar selama pembelajaran berlangsung. d) Menyusun tes hasil belajar.

2) Pelaksanaan Tindakan (Action)

Pada tahap ini dosen dan mahasiswa melaksanakan kegiatan pembelajaran di dalam kelas sesuai dengan rencana yang telah dituangkan dalam skenario pembelajaran. Kegiatan dilakukan pada tahap ini meliputi: a. Memberikan motivasi kepada mahasiswa 
tentang pentingnya penguasaan materi pembelajaran untuk menunjang materi lain. b. Memberikan apresiasi untuk mengetahui kesiapan mahasiswa atau mengarahkan mahasiswa ke materi pelajaran yang akan dibahas. c. Melaksanakan tahapan-tahapan pembelajaran sesuai dengan rencana pelaksanaan pembelajaran. Secara umum tahapan pembelajaran pada tiap siklus dilakukan dengan cara: 1). Membagi mahasiswa menjadi beberapa kelompok (beranggotakan 5 orang). 2). Membagi lembar diskusi mahasiswa/permasalahan yang berbeda pada masing-masing kelompok. 3) Membimbing dan melakukan pemantauan mahasiswa dalam mendiskusikan lembar diskusi mahasiswa. 4). Masing-masing kelompok mempresentasikan hasil diskusinya di depan kelas. 5). Bersama-sama dengan mahasiswa membuat kesimpulan dari tugas-tugas yang dilakukan dalam kelompok. 6). Mengidentifikasikan kesulitan-kesulitan yang dihadapi mahasiswa dan dosen selama proses pembelajaran berlangsung.

3) Tahap Observasi (Observation)

Kegiatan observasi dilakukan secara kontinyu pada setiap kali berlangsungnya pelaksanaan tindakan. Kegiatan ini meliputi:

a. Mengamati aktivitas mahasiswa dan dosen serta mencatat semua hambatan, kesulitan yang dialami selama pembelajaran. Aktivitas dosen dan mahasiswa direkam dengan menggunakan lembar observasi yang dilakukan oleh anggota peneliti (observer). Hasil dari kegiatan observasi pembelajaran digunakan untuk memperbaiki pelaksanaan tindakan tindakan pada siklus berikutnya.

b. Mengevaluasi pencapaian hasil belajar dengan memberikan tes pada setiap akhir siklus.

4) Refleksi (Reflektion)

Kegiatan yang dilaksanakan pada tahap refleksi ini adalah:

a. Bersama-sama dengan anggota tim menganalisa hasil evaluasi, hasil obsrvasi dan temuan lain pada saat berlangsung pembelajaran pada pelaksanaan tindakan I.

b. Mencari alternative pemecahan dari temuantemuan tersebut sebagai bahan masukan dalam perencanaan tindakan pada siklus berikutnya (siklus II).

c. Tindakan pada siklus II ditentukan berdasarkan hasil refleksi pada siklus I. .

Pembelajaran pada Siklus II meliputi Pelaksanaan dan langkah siklus II mirip dengan siklus I yang merupakan penyempurnaan-penyempurnaan dari siklus sebelumnya. Cara pengumpulan data sebagai berikut : Data tentang aktivitas belajar mahasiswa dalam proses pembelajaran menggunakan lembar observasi mahasiswa. Data tentang kemampuan dosen dalam melaksanakan proses pembelajaran dengan model pembelajaran kooperatif tipe Investigasi kelompok menggunakan lembar observasi dosen. Data hasil belajar mahasiswa.

\section{HASIL PENELITIAN DAN PEMBAHASAN}

\section{A. Hasil Penelitian}

Penelitian ini telah dilaksanakan dalam 2 siklus dengan subyek penelitian program studi pendidikan matematika FKIP Unram tahun 20192020 yang berjumlah 35 orang. Setiap siklus terdiri dari beberapa tahap yaitu tahap perencanaan, pelaksanaan, observasi, evaluasi dan refleksi. Datadata hasil penelitian yang diperoleh dalam tiap siklus dijelaskan sebagai berikut:

Siklus I

a. Tahan Perencanaan

Pada tahap ini dosen (peneliti) mempersiapkan instrument penelitian sebagai berikut:

1. Menyusun rencana pelaksanaan perkuliahan (RPS).

2. Membuat lembar Diskusi .

3. Membuat lembar observasi kegiatan mahasiswa beserta pedoman pengisiannya.

4. Membuat lembar observasi kegiatan dosen beserta pedoman pengisiannya.

5. Menyusun soal evaluasi siklus I yang berupa tes

\section{b. Tahap Pelaksanaan Tindakan}

Pada tahap ini proses belajar mengajar dilaksanakan dalam 1 kali pertemuan (3 jam pelajaran). Dalam pelaksanaan pembelajaran pada setiap pertemuan dalam siklus 1 ini dibagi menjadi 4 bagian utama yaitu pendahuluan, pengembangan, aplikasi dan penutup. Pada tahap pendahuluan dosen mensosialisasikan tentang model pembelajaran yang digunakan dalam proses perkuliahan model pembelajaran kooperatif tipe Investigasi kelompok. Pada pertemuan pertama Dosen membagi mahasiswa menjadi kelompok-kelompok belajar yang anggotanya masing-masing terdiri dari 5 orang mahasiswa. Setap anggota dalam kelompok terdiri dari mahasiswa-mahasiswa yang memiliki kemampuan yang heterogen. Heterogenitas kelonpok diharapkan supaya keaktifan mahasiswa dalam berdiskusi menjadi seimbang antara kelompok satu dengan kelompok yang lain.

Pada tahap pengembangan dosen memberikan lembar diskusi pada setiap kelompoknya. Selanjutnya tiap kelompok mendiskusikan tugas yang diberikan. Setelah diskusi selesai dosen meminta 
satu kelompok yang diwakili oleh salah satu anggotanya untuk mempresentasikan hasil diskusinya. Kelompok lain menanggapi hasil presentasi kelompok dengan mengajukan pertanyaan atau mengemukakan pendapatnya. Setelah diskusi selesai dosen mengklarifikasi kesalahan terhadap hasil diskusi mahasiswa. Hal ini dimaksudkan untuk menyamakan persepsi dan jika ada yang belum jelas dosen meminta mahasiswa bertanya dan mengemukakan pendapatnya.

Pada tahap aplikasi, dosen memberikan contoh soal kemudian memberikan soal latihan pada tiap-tiap anggota kelompok agar mahasiswa terampil dalam menerapkan konsep yang telah ditemukan untuk menyelesaikan soal. Dosen membimbing mahasiswa selama latihan berlangsung. Pada kegiatan akhir dosen meminta mahasiswa untuk mengumpulkan jawaban dari soal latihan tersebut. Hal ini bertujuan untuk mengetahui tingkat pemahaman masing-masing mahasiswa.

Pada tahap penutup dosen meminta beberapa mahasiswa untuk menyimpulkan materi hasil pembelajaran yang telah berlangsung. Kemudian dosen menambahkan kekurangan dari simpulan mahasiswa.

\section{c. Tahap Observasi}

Pada proses pelaksanaan pembelajaran, aktivitas dosen dan mahasiswa observer. Adapun hasil observasi kegiatan perkuliahan pada tabel 1 .

Dari analisa pengamatan aktivitas mahasiswa dan komentar observer diperoleh bahwa interaksi antara dosen dan mahasiswa masih kurang, suasana kelas kurang tertib dan banyak mahasiswa kurang aktif dalam diskusi, partisipasi mahasiswa dalam menyimpulkan hasil pembelajaran masih kurang.

Hasil observasi kegiatan dosen diketahui bahwa pengaturan waktu untuk alokasi diskusi dan mengerjakan latihan soal dalam skenario pembelajaran perlu ditambahkan agar sesuai dengan pelaksanaan pembelajaran, bimbingan dan pengarahan dalam pembelajaran kepada tiap-tiap kelompok masih kurang, baik dalam menanggapi pertanyaan maupun dalam membuat rangkuman, pengelolaan kelas masih kurang, ini terlihat dari banyaknya mahasiswa masih main-main dan tidak serius dalam berdiskusi.

Berdasarkan hasil evaluasi pembelajaran dilakukan pada akhir siklus I diperoleh data seperti pada tabel 2.

\section{d. Refleksi}

Setelah dilakukan evaluasi dari penerapan pembelajaran menggunakan pembelajaran kooperatif tipe investigasi kelompok ini diperoleh data aktivitas belajar mahasiswa masih belum aktif. Nilai ini masih belum memenuhi indikator pencapaian yang telah ditetapkan dalam indikator kinerja.

Dilihat dari hasil evaluasi yang diperoleh pada siklus I ternyata belum mencapai hasil yang diharapkan. Karena itu kegiatan pembelajaran dilanjutkan pada siklus II dengan memperbaiki kelemahan-kelemahan yang ditemukan dalam siklus I diantaranya adalah meningkatkan interaksi mahasiswa dengan dosen, menambahkan alokasi waktu untuk diskusi, membimbing mahasiswa dalam mengerjakan LKS, memperbaiki pengelolaan kelas dan membimbing mahasiswa dalam membuat kesimpulan.

Dari hasil observasi mahasiswa, hasil observasi dosen dan evaluasi mahasiswa siklus I, terdapat beberapa kekurangan yang akan diperbaiki pada siklus II. Setelah dilakukan analisa terhadap kekurangan-kekurangan tersebut, maka dilakukan perbaikan-perbaikan pada siklus II antara lain:

1. Dosen mengecek tiap kelompok untuk membantu mengorganisasi tugas mahasiswa

2. Dosen mendatangi dan memberikan bimbingan kepada tiap-tiap kelompok yang masih terlihat kebingungan dalam mengisi dan menyelesaikan lembar diskusi mahasiswa

3. Dosen memberikan bimbingan terhadap mahasiswa yang masih bingung dalam mengerjakan tugas yang diberikan.

4. Dosen menyuruh mahasiswa yang pintar agar mau membantu temannya yang masih pasif dan mahasiswa yang kurang pintar agar tidak malu meminta bantuan pada temannya yang lebih pintar serta memperjelas tugas mereka masingmasing dalam diskusi kelompok.

5. Mengaktifkan tanya jawab, menyarankan kepada seluruh mahasiswa untuk berani berbicara dengan jalan menunjuk beberapa orang mahasiswa agar menanggapi pernyataan dosen atau menjawab pertanyaan dosen.

6. Hasil diskusi dan latihan soal yang di presentasikan ke depan kelas adalah hasil dari kelompok yang kurang aktif dan hasil dari mahasiswa yang kurang memperhatikan waktu diskusi kelompok. Apabila terdapat kekeliruan dalam struktur penulisan jawaban, dosen akan memperbaiki dan memberikan contoh yang benar.

7. Lebih mengaktifkan mahasiswa dalam melakukan kegiatan pembelajaran.

8. Dosen memberikan klasrifikasi terhadap permasalahan yang dipecahkan.

Siklus II

a. Tahap Perencanaan

1. Menyusun rencana pelaksanaan
perkuliahan (RPS). 
2. Membuat lembar Diskusi .

3. Membuat lembar observasi kegiatan mahasiswa beserta pedoman pengisiannya.

4. Membuat lembar observasi kegiatan dosen beserta pedoman pengisiannya.

5. Menyusun soal evaluasi siklus I yang berupa tes

b. Tahap Pelaksanaan Tindakan

Tahap siklus II ini hampir sama dengan siklus I, demikian juga anggota kelompok pada siklus II sama seperti siklus I. akan tetapi ada perbaikanperbaikan yang dilakukan pada siklus II ini sesuai hasil refleksi pada siklus I.

Perbaikan-perbaikan yang dilakukan pada siklus II diantaranya (1) Menambahkan alokasi waktu untuk diskusi dan pengerjaan latihan, (2) Memotivasi mahasiswa untuk aktif dalam diskusi kelompok, aktif dalam bertanya dan berpendapat, dan (3) Memperhatikan ketertiban jalannya diskusi agar sesuai dengan alokasi waktu yang ditetapkan dalam skenario perkuliahan.

\section{c. Tahap Observasi}

Hasil observasi kegiatan belajar mengajar, baik dosen maupun mahasiswa sudah terlaksana dengan baik. Hal ini dapat dilihat dari data analisis observasi kegiatan mahasiswa dengan kategori sangat memuaskan. Demikian juga halnya dengan hasil observasi kegiatan dosen, semua deskriptor menunjukkan kegiatan yang baik sekali.

Rata-rata tingkat aktivitas mahasiswa pada siklus II menunjukkan peningkatan dibandingkan dengan siklus sebelumnya, pada siklus ke II ini berkategori sangat memuaskan.

Berdasarkan hasil evaluasi pembelajaran dilakukan pada akhir siklus II diperoleh data pada tabel 4.

Tabel 1. Data kegiatan dosen dan aktivitas belajar mahasiswa selama pembelajaran siklus I

\begin{tabular}{ccccc}
\hline \multirow{2}{*}{ Siklus } & \multicolumn{2}{c}{ Kegiatan Dosen } & \multicolumn{2}{c}{ Aktivitas Belajar Mahasiswa } \\
\cline { 2 - 5 } & Skor & Kriteria & Skor & Kriteria \\
\hline I & 5,00 & Baik & 4,00 & Cukup aktif \\
\hline
\end{tabular}

Tabel 2 : Hasil evaluasi siklus 1

\begin{tabular}{cccccc}
\hline $\begin{array}{c}\text { Jumlah } \\
\text { Mahasiswa }\end{array}$ & Jumlah nilai & Nilai tertinggi & Nilai terendah & Rata-rata & $\begin{array}{c}\text { Ketuntasan } \\
\text { klasikal (\%) }\end{array}$ \\
\hline 35 & 2229 & 79 & 40 & 63,7 & 77 \\
\hline
\end{tabular}

Tabel 3. Data kegiatan dosen dan aktivitas belajar mahasiswa selama pembelajaran siklus II

\begin{tabular}{ccccc}
\hline \multirow{2}{*}{ Siklus } & \multicolumn{2}{c}{ Kegiatan Dosen } & \multicolumn{2}{c}{ Aktivitas Belajar Mahasiswa } \\
\cline { 2 - 5 } & Skor & Kriteria & Skor & Kriteria \\
\hline II & 6,00 & Baik & 5,00 & Aktif \\
\hline
\end{tabular}

Tabel 4 Hasil evaluasi siklus 2

\begin{tabular}{cccccc}
\hline $\begin{array}{c}\text { Jumlah } \\
\text { Mahasiswa }\end{array}$ & Jumlah nilai & Nilai tertinggi & Nilai terendah & Rata-rata & $\begin{array}{c}\text { Ketuntasan } \\
\text { klasikal (\%) }\end{array}$ \\
\hline 35 & 2520 & 87 & 67 & 72 & 85,7 \\
\hline
\end{tabular}

Dari hasil evaluasi pada siklus II diperoleh hasil belajar mahasiswa sudh mencapai ketuntasan klasikal sesuai dengan indicator keberhasilan dalam pelaksanaan penelitian ini.

\section{d. Tahap Refleksi}

Berdasarkan hasil observasi kegiatan dosen diperoleh bahwa proses kegiatan belajar mengajar sudah dilaksanakan sesuai dengan skenario pembelajaran. Demikian juga halnya dnegan aktivitas mahasiswa menunjukkan peningkatan dari siklus I ke siklus II.

\section{B. Pembahasan}

Pada siklus I tahap perencanaan, peneliti menyiapkan bahan-bahan yang diperlukan untuk 
kegiatan pelaksanaan pembelajaran mulai dari perangkat pembelajaran RPS, media perkuliahan sampai pembuatan lembar observasi kegiatan dosen dan aktivitas mahasiswa. Pada tahap pelaksanaan, pembelajaran berlangsung sesuai dengan rencana pelaksanaan pembelajaran yang telah disusun. Pada tahap ini pelaksanaan kegiatan diskusi dan presentasi kurang memuaskan karena cara ini dirasakan masih baru oleh mahasiswa, sehingga mahasiswa masih canggung. Tahap observasi pelaksanaan siklus I menunjukkan bahwa tingkat aktivitas mahasiswa pada siklus I belum mencapai indikator penelitian. Faktor-faktor yang menyebabkan hal tersebut tidak terlepas dari kekurangan-kekurangan yang dilakkukan oleh dosen selama pembelajaran berlangsung. Kekurangan-kekurangan tersebut di antaranya adalah pengelolaan kelas yang kurang maksimal sehingga banyak mahasiswa yang kurang aktif dalam diskusi kelompok. Kurang meratanya bimbingan dosen pada tiap-tiap kelompok belajar selama diskusi dan mengerjakan latihan soal. Ketiga, kurangnya waktu yang digunakan untuk diskusi dan pengerjaan soal latihan.

Berdasarkan hasil analisis pelaksanaan siklus I, skor aktivitas belajar mahasiswa kurang aktif. Ketidakaktifan mahasiswa selama pembelajaran pada siklus I banyak disebabkan oleh interaksi dosen dan mahasiswa yang masih jarang. Hal ini diduga karena adanya mahasiswa yang bermain-main selama pembelajaran berlangsung. Demikian juga halnya dengan partisipasi mahasiswa dalam menyimpulkan hasil belajar menunjukkan hasil yang kurang menggembirakan. Banyak ditemukan mahasiswa dalam kelompok yang tidak aktif ikut merumuskan kesimpulan hasil belajar.

Kelemahan-kelemahan yang dilakukan pada siklus I akan diperbaiki pada siklus II yaitu meningkatkan interaksi mahasiswa dengan dosen baik dalam bertanya maupun mengemukakan pendapat dengan mengunjungi tiap-tiap kelompok secara merata, menambahkan alokasi waktu untuk diskusi dan pengerjaan latihan dalam skenario pembelajaran, membimbing mahasiswa dalam pengerjaan lembar diskusi mahasiswa maupun dalam mengerjakan latihan soal-soal secara merata pada tiap-tiap kelompok, meminta kelompok untuk menanggapi pertanyaan dari kelompok lain terhadap hasil temuannya, memperbaiki pengelolaan kelas dengan memberikan peringatan atau hukuman kepada mahasiswa apabila main-main dalam diskusi, membimbing mahasiswa dalam membuat ringkasan terhadap hasil temuannya.

Aktivitas belajar mahasiswa pada siklus II mengalami peningkatan dari siklus sebelumnya. Meskipun kategorinya sama dengan siklus I akan tetapi kalau dilihat dari pencapaian skor aktivitas menunjukkan peningkatan. Kesiapan mahasiswa dalam mengikuti pelajaran, aktivitas mahasiswa selama pembelajaran, interaksi mahasiswa dengan dosen, aktivitas mahasiswa dalam diskusi kelompok, dan partisipasi mahasiswa dalam membuat kesimpulan berkategori aktif. Sedangkan antusiasme mahasiswa dalam mengikuti pelajaran dan interaksi mahasiswa dengan mahasiswa berkategori sangat aktif. Kegiatan pembelajaran yang dilakukan dosen dan mahasiswa sesuai dengan skenario pembelajaran. Demikian juga pada siklus ke II ini indikatorindikator kinerja yang menjadi target penelitian sudah tercapai. Hasil observasi kegiatan dosen dan mahasiswa sangat memuaskan.

Selain kesiapan belajar, dalam proses belajar mengajar juga dipengaruhi oleh sarana dan sumber belajar [16-18]. Penggunaan sarana dan sumber belajar memungkinkan mahasiswa dapat memahami pelajaran sebaik-baiknya. Apabila mahasiswa sudah memiliki kesiapan belajar maka aktivitas mahasiswa dalam proses belajar akan meningkat, Jika aktivitas meningkat maka hasil belajar akan meningkat pula [19-21]. Hal ini sesuai dengan hasil belajar yang diperoleh dari siklus I ke siklus II. Hasil yang baik dalam belajar ini juga didukung oleh tingkat kemampuan dosen yang menyebabkan belajar mahasiswa juga ikut meningkat.

\section{KESIMPULAN}

Berdasarkan hasil penelitian diperoleh kesimpulan sebagai berikut penerapan model pembelajaran kooperatif tipe investigasi kelompok dapat meningkatkan hasil belajar Biologi Umum mahasiswa kelas E program studi pendidikan matematika FKIP Universitas Mataram tahun 20192020. Hal ini dapat dilihat dari peningkatan hasil belajar dan aktivitas kegiatan pembelajaran yang dilakukan dosen dan mahasiswa.

\section{DAFTAR PUSTAKA}

[1] Safitri, N. L. (2019). Analisis Peningkatan Partisipasi Aktif Mahasiswa Melalui Penerapan Model Pembelajaran Kooperatif Dengan Metode Kancing Warna Pada Mata Kuliah Strategi Belajar Mengajar. Education and Human Development Journal, 4(1), 1-10.

[2] Ali, M., \& Setiani, D. D. (2019). Pengaruh model discovery learning terhadap hasil belajar peserta didik pada konsep jamur. Bioedusiana: Jurnal Pendidikan Biologi, 3(2), 59-63.

[3] Indriwati, S. E., Susilo, H., \& Anggrella, D. P. (2019). Penerapan Model Pembelajaran Inkuiri Terbimbing Berbasis Lesson Study Pada Matakuliah Keanekaragaman Hewan Untuk Meningkatkan Kecakapan Komunikasi 
Dan Hasil Belajar Kognitif Mahasiswa Pendidikan Biologi. Jurnal Pendidikan Biologi, 9(2), 38-46.

[4] Sadikin, A., \& Hakim, N. (2019). Buku Ajar Berbantuan Model Pembelajaran Everyone is A Teacher Here: Upaya Meningkatkan Keterampilan Dasar Mengajar Calon Guru Biologi. Assimilation: Indonesian Journal of Biology Education, 2(2), 47-51.

[5] Anonim. 2005. Peraturan Pemerintah Republik Indonesia Nomor 19 Tahun 2005 tentang Standar Nasional Pendidikan.

[6] Sagala, H. Syaiful. 2008. Konsep dan Makna Pembelajaran. Bandung : ALFABETA.

[7] Jufri, W., \& Dj, D. S. (2010). Efektivitas pembelajaran sains berbasis inkuiri dengan strategi kooperatif dalam meningkatkan keterampilan berpikir siswa SMP. Jurnal Pendidikan dan Pembelajaran (JPP), 17(2), 159-165.

[8] Arizona, K., Harjono, A., \& Jufri, A. W. (2013). Pengaruh Implementasi Media Tiga Dimensi Kemagnetan Berbasis Inkuiri (MTDKBI) melalui Strategi Kooperatif terhadap Kecakapan Sosial. ERUDIO (Journal of Educational Innovation), 1(2).

[9] Gayatri, I. G. A. S., Jekti, D. S. D., \& Jufri, A. W. (2013). Efektifitas pembelajaran berbasis masalah (PBM) dan strategi kooperatif terhadap kemampuan menyelesaikan masalah dan hasil belajar kognitif biologi ditinjau dari kemampuan akademik awal siswa kelas $\mathrm{X}$ SMA Negeri 3 Mataram. Jurnal Pijar Mipa, 8(2).

[10] Fahruddin, F., Jufri, A. W., \& Jamaluddin, J. (2016). Pengaruh Model Pembelajaran Kooperatif Terhadap Hasil Belajar Kognitif Ditinjau Dari Kemampuan Akademik Mahasiswa. Erudio Journal of Educational Innovation, 2(2), 41-48.

[11] Harjono, A., Jufri, W., \& Arizona, K. (2017). Implementasi Media Tiga Dimensi Kemagnetan Berbasis Inkuiri Melalui Strategi Kooperatif Terhadap Sikap Ilmiah Siswa. Jurnal Pendidikan Fisika dan Teknologi, 1(1), 15-23.

[12] Jufri, W. (2014). Peranan Perangkat Pembelajaran Berbasis Inkuiri dengan Strategi Kooperatif terhadap Perkembangan Keterampilan Berpikir Kritis. Jurnal Pendidikan Biologi, 1(1).

[13] Listiana, L. (2013, July). Pemberdayaan Keterampilan Berpikir dalam Pembelajaran Biologi melalui Model Kooperatif Tipe GI
(Group Investigation) dan TTW (Think, Talk, Write). In Proceeding Biology Education Conference: Biology, Science, Enviromental, and Learning (Vol. 10, No. 1).

[14] Suartika, K., Arnyana, I. B., \& Setiawan, G. A. (2013). Pengaruh Model Pembelajaran Kooperatif Tipe Group Investigation (Gi) Terhadap Pemahaman Konsep Biologi Dan Keterampilan Berpikir Kreatif Siswa SMA. Jurnal Pendidikan dan Pembelajaran IPA Indonesia, 3(1).

[15] Kholina, N., Pribadi, T. A., \& Ridlo, S. (2013). Penerapan Investigasi Kelompok Berbantuan Multimedia Materi Identifikasi Bakteri. Journal of Biology Education, 2(1).

[16] Litasari, K. N., Setiati, N., \& Herlina, L. (2014). Profil pembelajaran biologi berbasis laboratorium dan implikasinya terhadap hasil belajar siswa di SMA Negeri se-Kabupaten Semarang. Journal of Biology Education, 3(2).

[17] Mujisuciningtyas, N. (2017). Pengaruh Kemandirian Belajar Dan Sarana Prasarana Pembelajaran Terhadap Hasil Belajar Praktik Di SMK Negeri 2 Tuban. Jurnal Ekonomi Pendidikan Dan Kewirausahaan, 2(1), 103115.

[18] Ramdani, S. D., Maulani, I., \& Fawaid, M. (2019). Peran Sarana Pembelajaran dalam Mendukung Kemampuan Keterampilan Siswa SMK Program Keahlian Teknik Pemesinan Serang. Jurnal Dinamika Vokasional Teknik Mesin, 4(2), 150-157.

[19] Rijal, S., \& Bachtiar, S. (2015). Hubungan antara Sikap, Kemandirian Belajar, dan Gaya Belajar dengan Hasil Belajar Kognitif Siswa. Jurnal Bioedukatika, 3(2), 15-20.

[20] Rohwati, M. (2012). Penggunaan education game untuk meningkatkan hasil belajar IPA biologi konsep klasifikasi makhluk hidup. Jurnal Pendidikan IPA Indonesia, 1(1).

[21] Setiawan, I. G. A. N., \& Nyoman, G. A. (2008). Penerapan pengajaran kontekstual berbasis masalah untuk meningkatkan hasil belajar biologi siswa kelas x2 sma laboratorium singaraja. Jurnal Penelitian dan Pengembangan Pendidikan, 2(1), 42-59.

[22] Mertha, I. G., Al Idrus, A., Ilhamdi, M. L., Artayasa, I. P., \& Merta, I. W. (2014). Monitoring Dan Evaluasi Proses Perkuliahan Di Progra Studi Pendidikan Biologi Fkip Universitas Mataram Pada Semester Genap Tahun Akademik 2013/2014. Jurnal Pijar Mipa, 9(2). 